\title{
The environmental index of the rare earth elements in conodonts: Evidence from the Ordovician conodonts of the Huanghuachang Section, Yichang area
}

\author{
CHEN XiaoHong $^{1 *}$, ZHOU Lian $^{2}$, WEI Kai ${ }^{1}$, WANG Jin ${ }^{2} \&$ LI ZhiHong ${ }^{1}$ \\ ${ }^{1}$ Wuhan Institute of Geology and Mineral Resources, Wuhan 430223, China; \\ ${ }^{2}$ Geological Processes and Mineral Resources, State Key Laboratory of China University of Geosciences, Wuhan 430074, China
}

Received June 3, 2011; accepted August 31, 2011; published online October 17, 2011

\begin{abstract}
High-resolution microanalysis was performed on conodonts collected from the Huanghuachang section in the Yichang area using laser ablation inductively coupled plasma mass spectrometry (LA-ICP-MS). This region is regarded as a standard section for the division and correlation of the Ordovician system in southern China. The results show that the values of $(\mathrm{La} / \mathrm{Yb})_{\mathrm{N}}$ and $(\mathrm{La} / \mathrm{Sm})_{\mathrm{N}}$ decrease, while the values of $\delta \mathrm{Ce}$ increase as seawater deepens and energy decreases. As the sedimentary environment changes from shallow-water carbonate platform to platform margin to open continental shelf to shelf basin, rare earth element distribution curves gradually transform from a right inclined pattern to a flat pattern to a left inclined pattern and a hat-shaped pattern. The present work proves that the values and distributive patterns of rare earth elements in conodonts correspond with the sedimentary environment, and therefore provide reliable evidence for the application of rare earth element concentrations of biogenic phosphates such as conodonts for palaeoenvironmental reconstructions.
\end{abstract}

Ordovician, conodonts, rare earth elements, palaeoenvironmental, Yichang

Citation: Chen X H, Zhou L, Wei K, et al. The environmental index of the rare earth elements in conodonts: Evidence from the Ordovician conodonts of the Huanghuachang Section, Yichang area. Chin Sci Bull, 2012, 57: 349-359, doi: 10.1007/s11434-011-4788-1

Studies of the evolution mechanisms of palaeo-seawater and the reconstruction of palaeoenvironments with shells containing phosphates have received extensive global attention in recent years [1-5]. Although these studies have spanned the Paleozoic, and even included the Neoarchaean, the results are based on different materials (e.g. conodonts, shells, fishbones and others), methods and regions that are not sufficient to elucidate the effects of sedimentary environments, tectonic movements and diagenesis on the distribution of rare earth elements (REE) in phosphate fossils. Therefore, a systematic study of continuously distributed phosphate shells (conodonts) in the Ordovician section of Huanghuachang, Yichang area was conducted by Chen et al. [6], using laser ablation inductively coupled plasma mass spectrometry (LA-ICP-MS). The results show that conodonts in

*Corresponding author (email: yccxiaohong@ 163.com) the same section, but different sedimentary environments, have different REE distribution patterns that may be regarded as indicators of environment. Building on previous research, the present work aims to further disclose the effects of tectonic movement as well as palaeogeographical and palaeoenvironmental changes in the distributions of REE, and thus provide the scientific evidence for the application of REE patterns in conodonts to palaeogeographic and palaeoenvironmental research.

Geographically, Yichang, Hubei is a structurally undeformed area of the central Yangtze platform. Ordovician rocks, overlying Cambrian and underlying Silurian deposits, are widely distributed around the Huangling anticline (Figure 1). The Ordovician System, characterized by a stratigraphically continuous succession, has an excellent fossil record in which conodonts are most abundant. As a standard section for the division and correlation of the Ordovician in 


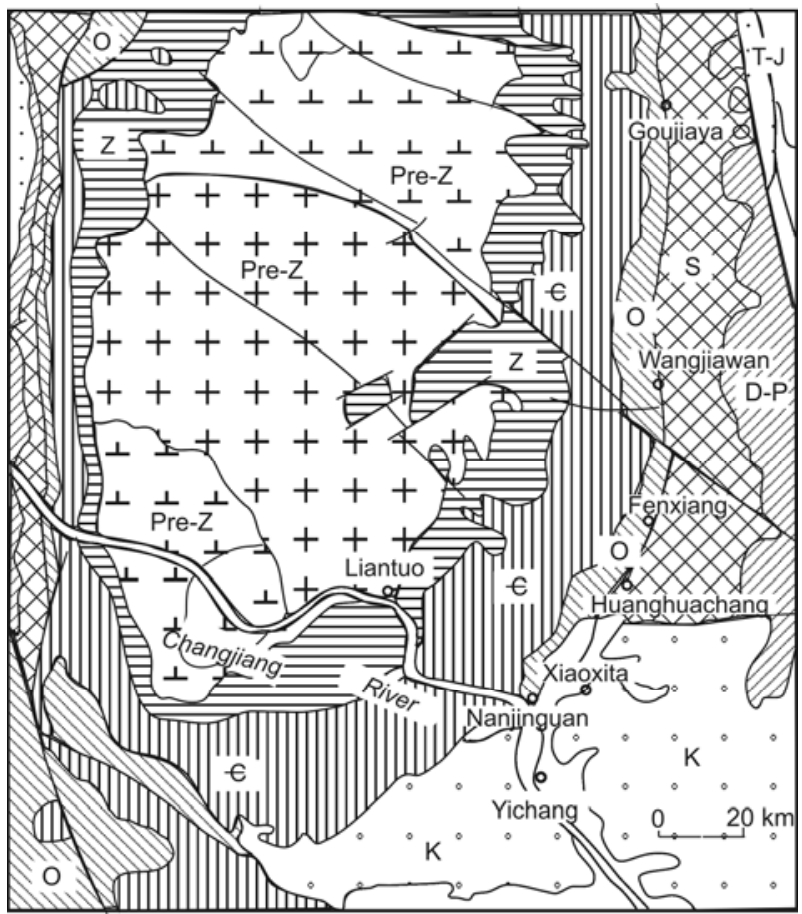

Figure 1 Generalized geological map of Yichang area (modified from [7]).

China, the Huanghuachang section is of great importance to studies of biostratigraphic and chronostratigraphic strata [8-11], and lithofacies palaeogeography [8,12-17]. Thus it is an ideal section for the study of REE distribution patterns of conodonts as well as their significance for palaeogeographic and palaeoenvironmental research.

\section{Materials and methods}

The Ordovician section in Huanghuachang has well outcrops along the highway from Yichang City to Xingshan County. It can be divided into nine formations, which in ascending order are: the Nanjinguan, Fenxiang and Honghuayuan formations of the Lower Ordovician, the Dawan and Guniutan formations of the Lower-Middle Ordovician, and the Miaopo, Baota, Linxiang, and Wufeng formations of the MiddleUpper Ordovician [7,8]. All of these strata are characterized by carbonates and abundant conodonts, with the exception of the Wufeng and Miaopo formations that mainly consist of black carbonaceous shale and the Fenxiang Formation that is yellowish-green shale. The lithostratigraphic units of the Ordovician discussed in this paper have been defined previously $[6,8]$. The serial numbers and positions of conodont specimens were obtained from Ordovician biostratigraphic research in the Huanghuachang section by Wang et al. [8]. The conodonts of the Ordovician in Huanghuachang of the Yichang area showed a color alternation index (CAI) in the range of 2-3, indicating little or no alternation during the period of late diagenesis and metamorphism [18]. In addition, because a conodont crown has the most stable REE compositions, whereas the other parts of the conodont are strongly affected by selective uptake during diagenesis [19], conodont crowns were the focus of this study.

The REE contents were analyzed by LA-ICP-MS (using an Elan 6100DRC system) at the State Key Laboratory of Geological Process and Mineral Resources, China University of Geosciences. The analytical method is as in Zhou et al. [20] and the results are listed in Table 1.

\section{Results and discussion}

\subsection{Values of $(\mathrm{La} / \mathrm{Yb})_{\mathrm{N}}$ and $(\mathrm{La} / \mathrm{Sm})_{\mathrm{N}}$}

The total rare earth element abundance ( $\mathrm{REE}$ ) in the Ordovician conodonts of the Huanghuachang section (from the Nanjinguan Formation to the Linxiang Formation) varies between 216 and $693 \mu \mathrm{g} / \mathrm{g}$. The values are much higher than those of modern Pacific Ocean water, but consistent with the results of previous studies on fish teeth and conodonts $[21,22]$. Ordovician conodonts from the Huanghuachang section have a large variation of $(\mathrm{La} / \mathrm{Yb})_{\mathrm{N}}$ values $(0.14-$ $19.66)$ but a small variation of $(\mathrm{La} / \mathrm{Sm})_{\mathrm{N}}$ values $(0.05-1.70)$ (Figure 2), suggesting that adsorption dominates the REE enrichment pattern in the region [22,23]. Based on the above results and analysis, the REE in the conodonts of the section accurately reflect the distribution patterns of REE in ancient seawater, considering that late diagenesis had little or no influence on the conodonts.

As shown in Figure 2, there is a weak positive correlation between $(\mathrm{La} / \mathrm{Yb})_{\mathrm{N}}$ and $(\mathrm{La} / \mathrm{Sm})_{\mathrm{N}}$ values. A similar correlation has also been reported in other periods such as the Devonian and Silurian $[22,24]$. From the Nanjinguan via Fenxiang and Honghuayuan to Dawan formations, the sedimentary environment changes gradually from shallow-water platform to open deeper-water continental margin [6,12-16]. This process was recorded by a decrease in the $(\mathrm{La} / \mathrm{Yb})_{\mathrm{N}}$ and $(\mathrm{La} / \mathrm{Sm})_{\mathrm{N}}$ values in the conodonts of the Huanghuachang section. Specifically, conodonts in shallow water platform sediments such as the Nanjinguan, Fenxiang and Honghuayuan formations have relatively high $(\mathrm{La} / \mathrm{Yb})_{\mathrm{N}}$ and $(\mathrm{La} / \mathrm{Sm})_{\mathrm{N}}$ values, whereas those in open continental shelf sediments like the Dawan Formation have relatively low $(\mathrm{La} / \mathrm{Yb})_{\mathrm{N}}$ and $(\mathrm{La} / \mathrm{Sm})_{\mathrm{N}}$ values. As for the Guniutan, Miaopo, Baota and Linxiang formations lying above the Dawan Formation, the sedimentary facies are mainly from the shelf-basin margin, similar to the Dawan Formation. Consequently, the ranges of conodont $(\mathrm{La} / \mathrm{Yb})_{\mathrm{N}}$ and $(\mathrm{La} / \mathrm{Sm})_{\mathrm{N}}$ values are close to those of the Dawan Formation. The correlation between variations in $(\mathrm{La} / \mathrm{Yb})_{\mathrm{N}}$ and $(\mathrm{La} / \mathrm{Sm})_{\mathrm{N}}$ values and sedimentary environment change may be attributed to the following. In the shallow-water near-shore environments, stronger erosion of terrigenous components, especially La-rich volcanic materials, contributed greatly to the relative higher values of $(\mathrm{La} / \mathrm{Yb})_{\mathrm{N}}$ and $(\mathrm{La} / \mathrm{Sm})_{\mathrm{N}}$ in seawater. 


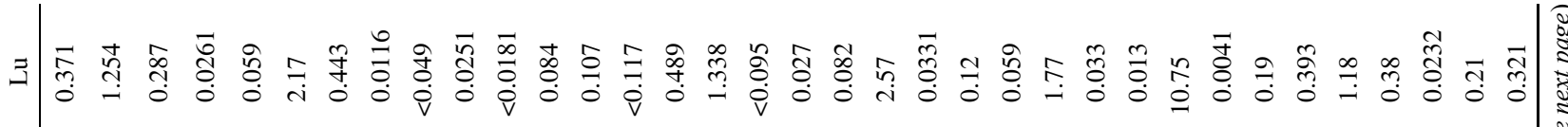

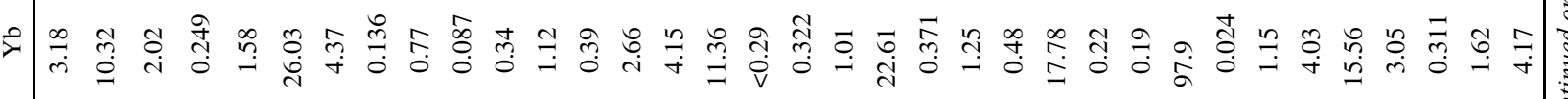

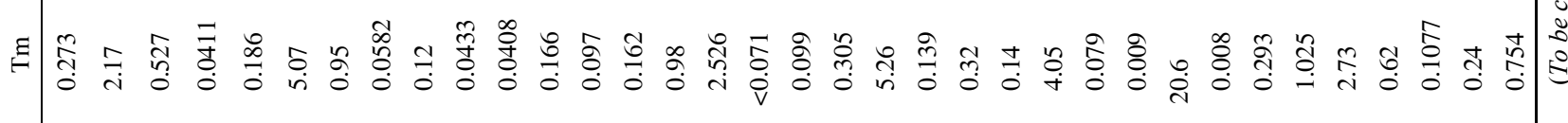

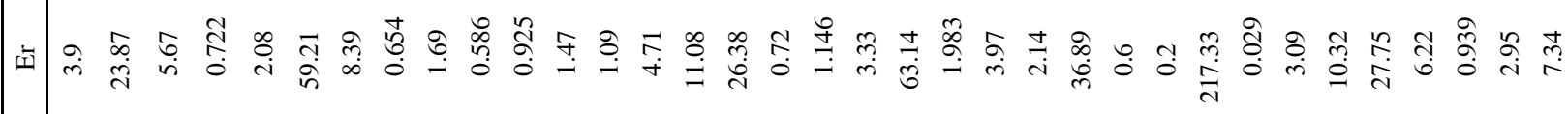

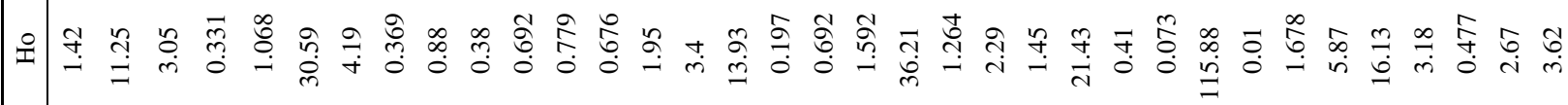

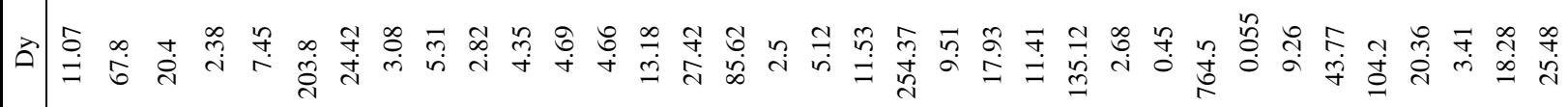

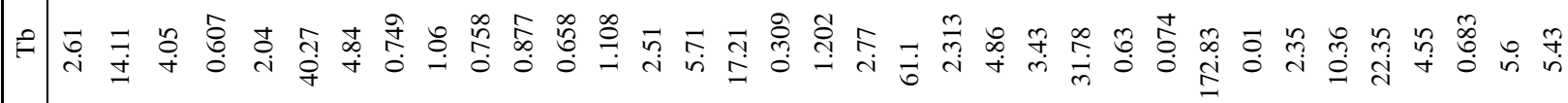

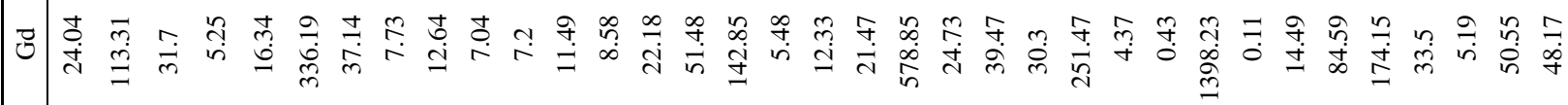

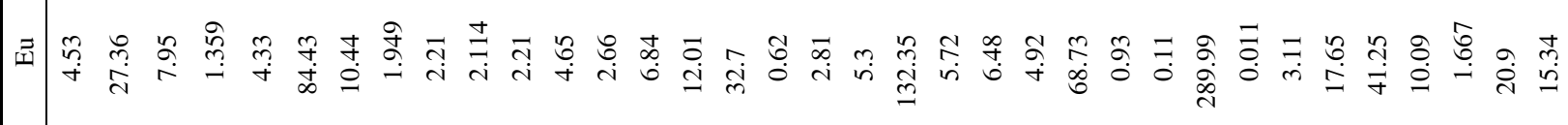

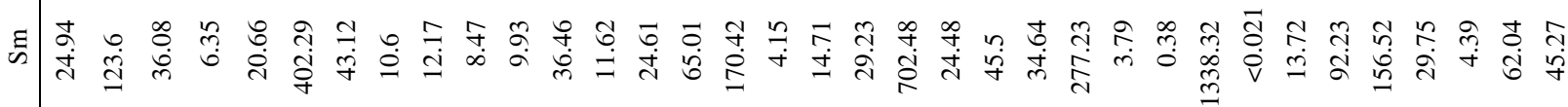
र a

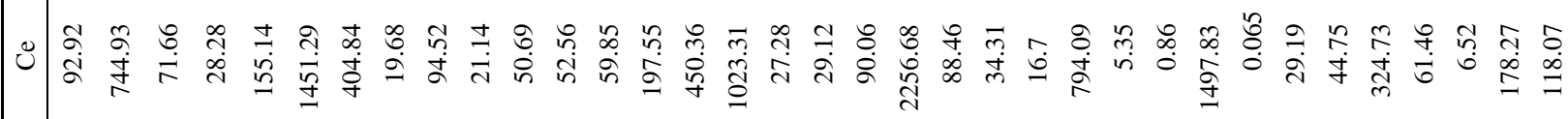

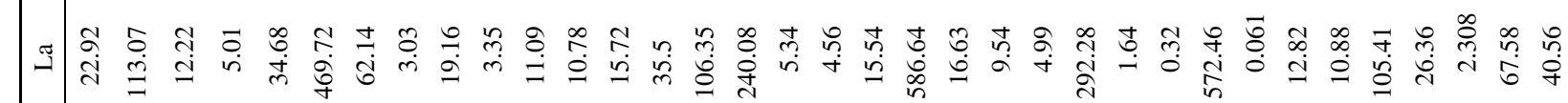

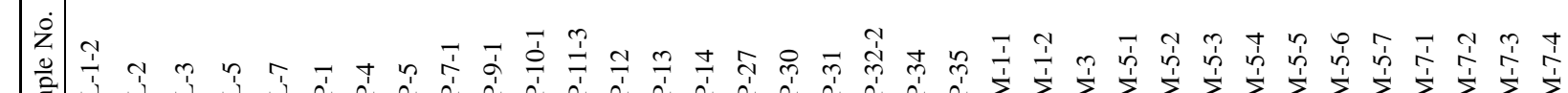

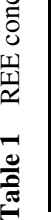

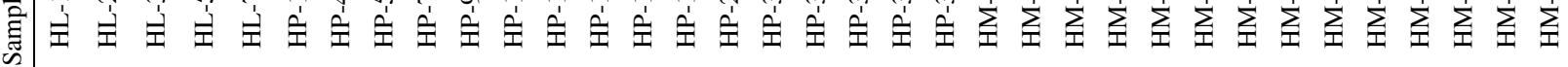
这 


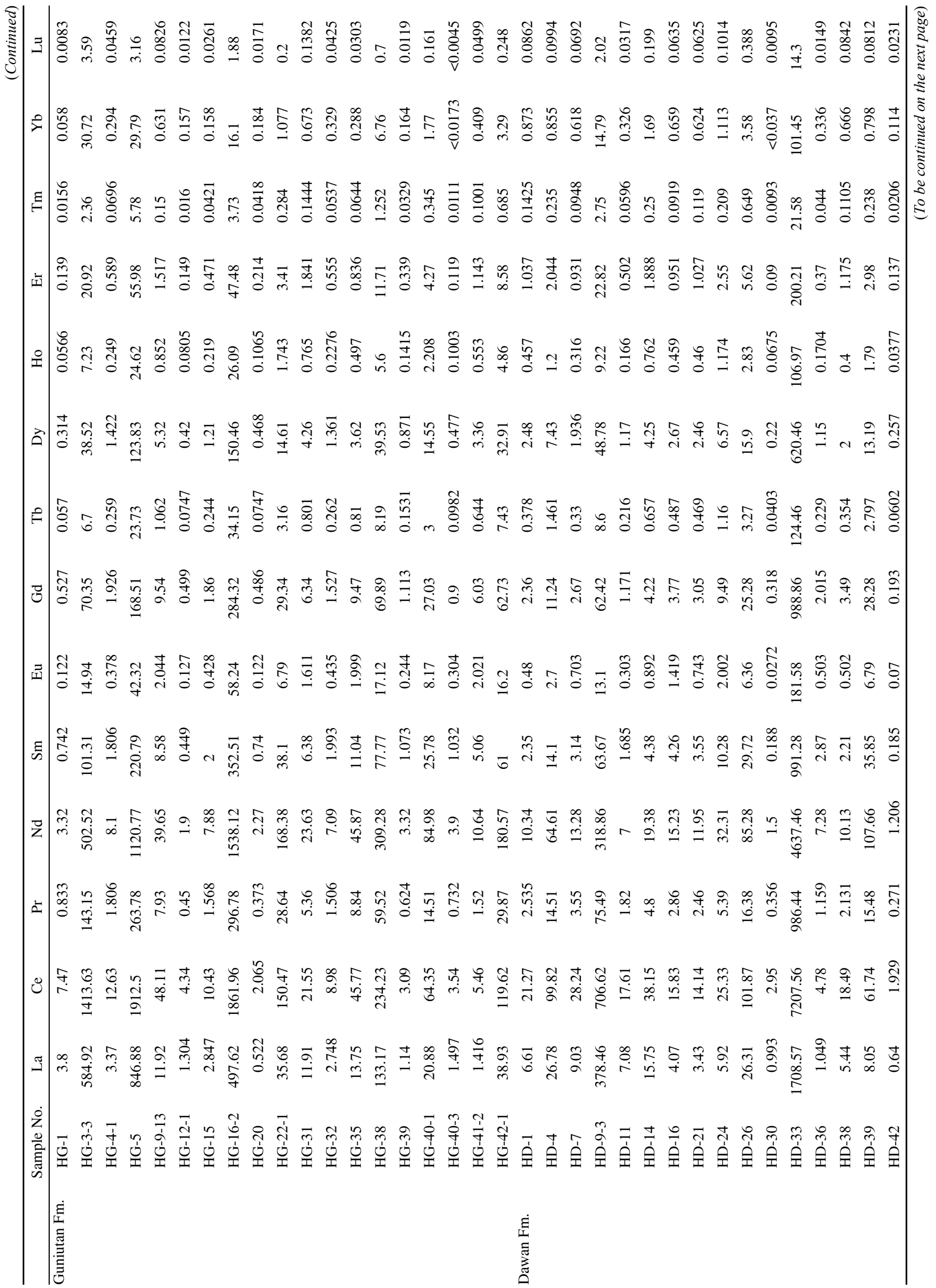




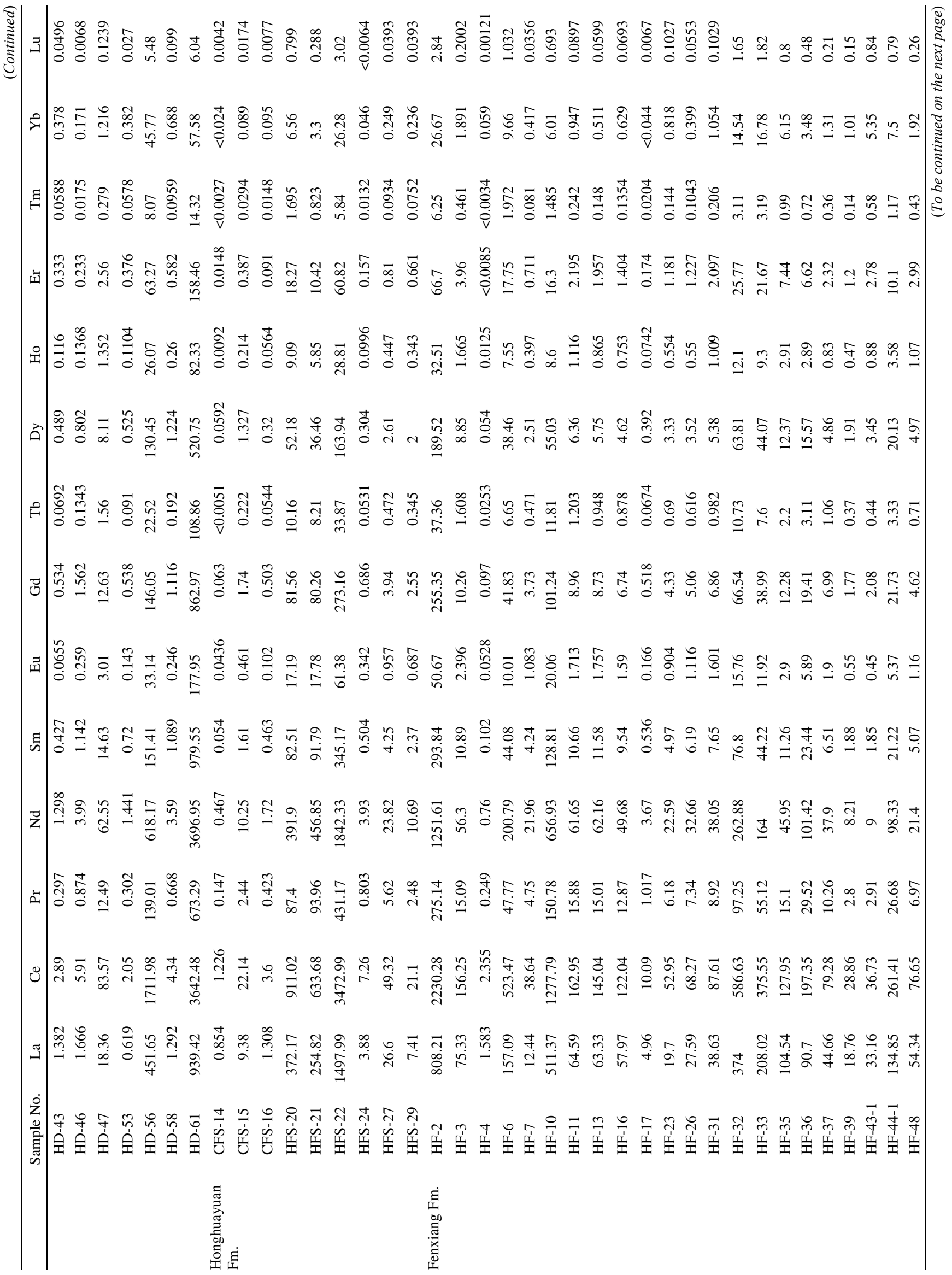




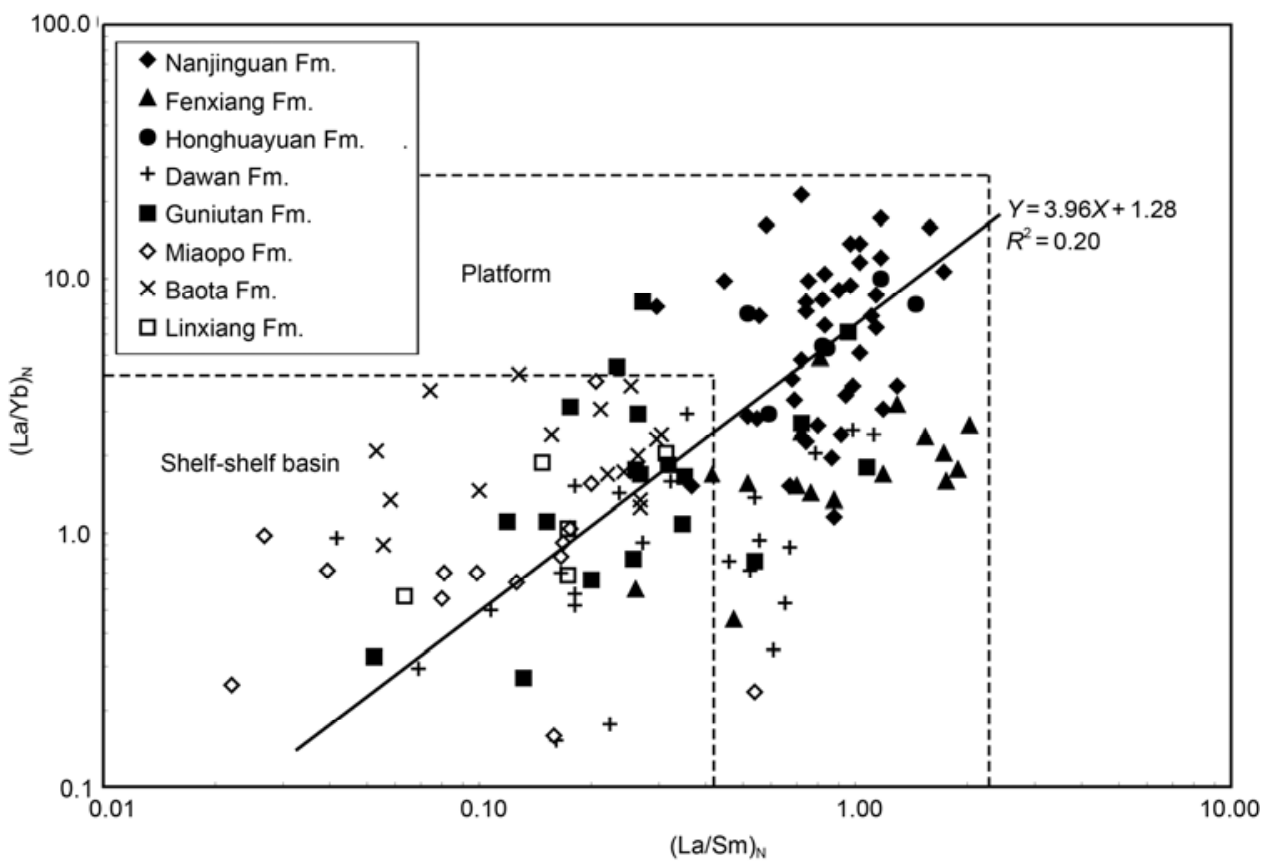

Figure 2 The relationship between normalized $\mathrm{La} / \mathrm{Yb}$ ratios and $\mathrm{La} / \mathrm{Sm}$ ratios for Ordovician conodonts of the Huanghuachang section, Yichang area.

On the contrary, in the deep-water environments far from shore, weaker erosion led to relatively lower values of $(\mathrm{La} / \mathrm{Yb})_{\mathrm{N}}$ and $(\mathrm{La} / \mathrm{Sm})_{\mathrm{N}}$. Therefore it can be concluded that $(\mathrm{La} / \mathrm{Yb})_{\mathrm{N}}$ and $(\mathrm{La} / \mathrm{Sm})_{\mathrm{N}}$ are potential indicators of waterdepth and palaeoenvironment.

\subsection{REE distribution patterns}

There are remarkable differences in the average North American shale (shown in Gromet et al. [25]) normalized REE distribution patterns of conodonts collected from different Ordovician strata in the Yichang Area. Among them, conodonts in the Nanjinguan and Honghuayuan formations of the Early Ordovician have right inclined REE patterns, with obvious light rare earth element (LREE) enrichment and heavy rare earth element (HREE) depletion (Figure 3a). This is in accordance with the relatively high $(\mathrm{La} / \mathrm{Yb})_{\mathrm{N}}$ and $(\mathrm{La} / \mathrm{Sm})_{\mathrm{N}}$ values in these strata. A possible reason for this is that the seawater in the shallow-water carbonate platform can more easily be affected by terrigenous material, especially La-rich volcanic materials [26].

Unlike the REE distribution curves of the Nanjinguan and Honghuayuan formations, the conodonts of the Fenxiang Formation exhibit flat and serrated REE distribution curves (Figure $3 b$ ). Such patterns can be compared to those of the Upper Ordovician deposits from the Southern Uplands of Scotland [27], indicating no apparent fractionation between the LREE and HREE, and a relatively stable structure with little effect from terrigenous materials [27,28]. In the previous study, the sedimentary environment of the Fenxiang Formation was considered to consist of platform margin shoals or organic reefs, far from shore [8].

There are at least three types of REE patterns for Dawan Formation conodonts (Figure 3c-e). The first type is a nearly flat and serrated distribution. This pattern is common in the Lower Member and the upper part of the Middle Member of the Dawan Formation, which has a sedimentary environment that is similar to the Fenxiang Formation. The second type, mainly observed in the Upper Dawan Formation, is characterized by a left inclination with a slight LREE depletion and HREE enrichment. Such patterns can be compared to those of the Ordovician cherts in North Qilian [29] and are close to those of the Atlantic and Pacific water signatures for the depth interval 600-2500 m [23], and to anoxic seawater (Black Sea, Saanich Inlet) and estuarine water (Chao Phraya) [5], indicating further deepening of the water body and decreasing influence of terrigenous materials on REE in the seawater during the period. That can be proved by globally distributed deep-water graptolites such as $U$. austrodentatus, Undlograptus sinodentatus, etc. $[8,12]$, and also by the globally anoxic event beginning at the Darriwillian [30]. The third type, namely bell-shaped patterns, exhibits a strong enrichment in middle rare earth element. Such patterns seldom appear in the Lower Member but gradually become common from the Middle to Upper Members of the Dawan Formation then to the Guniutan Formation. Such bell-shaped patterns most especially exist for conodonts in all strata above the top of the Guniutan Formation, including the Miaopo, Baota and Linxiang formations (Figure 3f).

There are two possible reasons for the variety of REE patterns in Dawan Formation conodonts. One is the gradual 

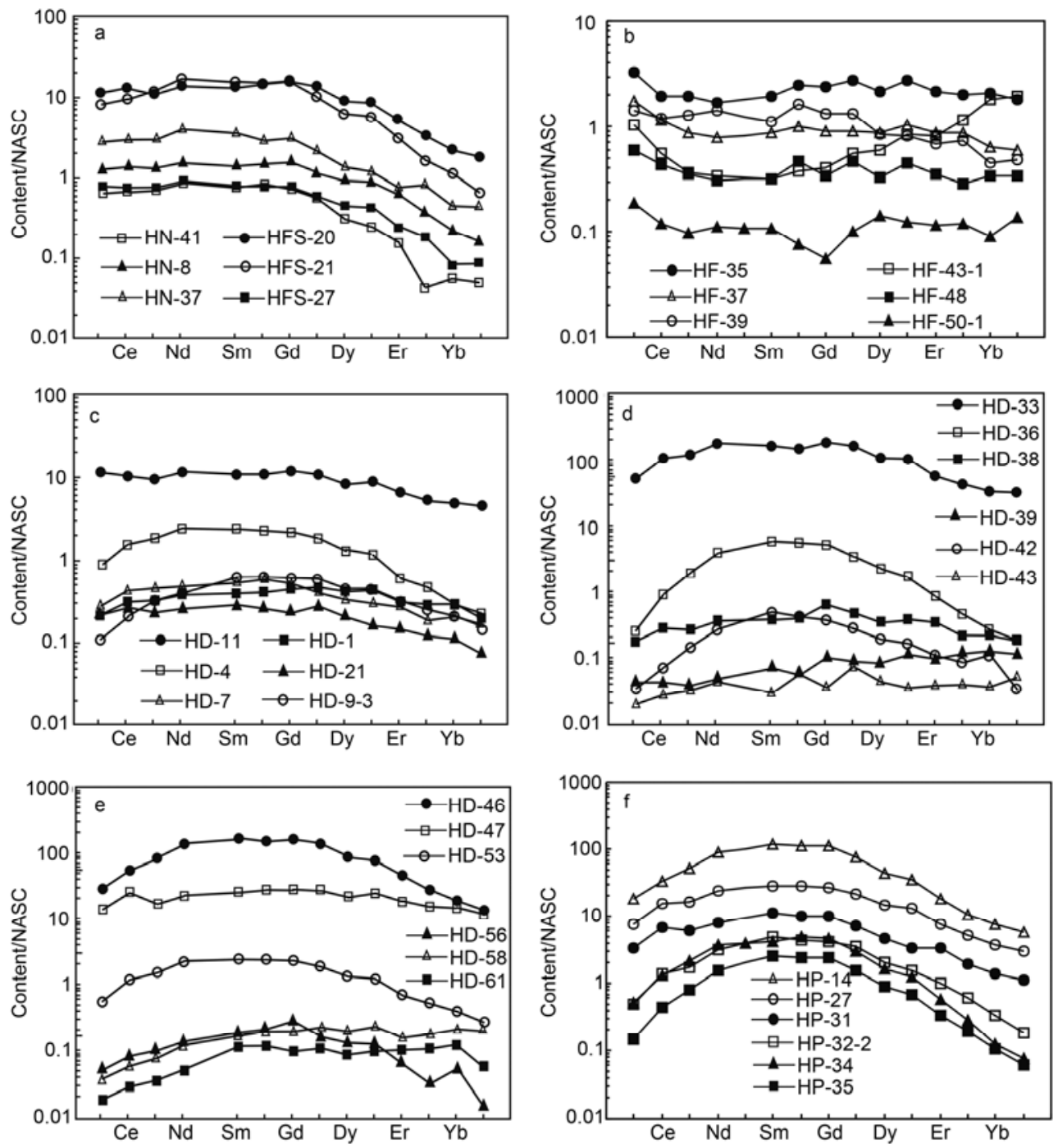

Figure 3 NASC-normalized REE patterns for Ordovicion conodonts of the Huanghuachang section, Yichang area. a, Nanjinguan and Honghuayuan formations; b, Fenxiang Formation; c, Lower Dawan Formation; d, Middle Dawan Formation; e, Upper Dawan Formation; f, Baota Formation.

deepening of seawater as the sedimentary environment changes from shallow-water platform to platform margin, then to shelf and finally to basin margin $[8,12,31]$. The other reason is the palaeotectonogeographic and palaeobiogeographic changes of the Yangtze Area that occurred after the deposition of the Middle Dawan Formation. According to the graphic correlation of the Ordovician chitinozoan ranges in South China, the sedimentation rate increased noticeably after the last appearance of Clavachitina langei in North Guizhou province [6]. Because Clavachitina langei is a chitinozoan index fossil from the latest period of the Early Ordovician, the increased sedimentation rate indicates a fast deposition at North Guizhou and East Chongqing on the leading edge of Qianzhong Upheaval after the Early Ordovician. This event accompanied with the continuous subsidence of the Yichang area suggests that the palaeotectonogeographic background of the region of the Middle Yangtze gradually changed from a simple carbonate plat- form in the Early Ordovician to analogous foreland basins in the Middle Ordovician. This foreland-like basin finished forming during the Late Ordovician [32]. From a palaeobiogeography aspect, the area of the Yangtze gradually changed from a warm middle-low latitude Laurentian-Siberian biogeographic region during the Early Ordovician to the cold middle-high latitude European-Asian biogeographic region after the Middle Ordovician [33]. Based on the above discussion, it can be concluded that the bell-shaped REE patterns of the Ordovician conodonts from the Huanghuachang section are controlled by palaeotectonogeographic and palaeobiogeographic variations in frequency and time. Thus the bell-shaped REE patterns may be the typical REE distribution patterns of the conodonts in a foreland basin, resulting from the combined effects of water depth and the introduction of terrigenous materials on the seawater REE rather than from diagenesis, which is in agreement with the CAI range (2-3) for conodonts [18,23,34]. 


\subsection{Ce anomalies}

Ce anomalies play a significant role in interpretations of water depth or chemical conditions $[1,35,36]$. Figure 4 shows the variation of $\mathrm{Ce}$ anomalies (expressed by $\delta \mathrm{Ce}$ values) from the Ordovician conodonts recovered from the Huanghuachang section in Yichang. Two different grades of Ordovician sea-level fluctuation in the Yangtze Gorges Area are also compared. Generally, an increasing trend exists in the Ce anomalies from the Lower to Upper Ordovician. This trend is in accordance with the gradually rising sea level and deepening water interpreted from earlier research of the local sedimentary history and palaeoecology of benthic fauna [6,7,12-16,37]. In particular, the Middle Nanjinguan, Fenxiang and Honghuayuan formations deposited on the carbonate platform-platform margin have weak-to-moderately negative $\mathrm{Ce}$ anomalies, indicating an oxygen-rich and shallow-water environment. However, the Lower and Upper

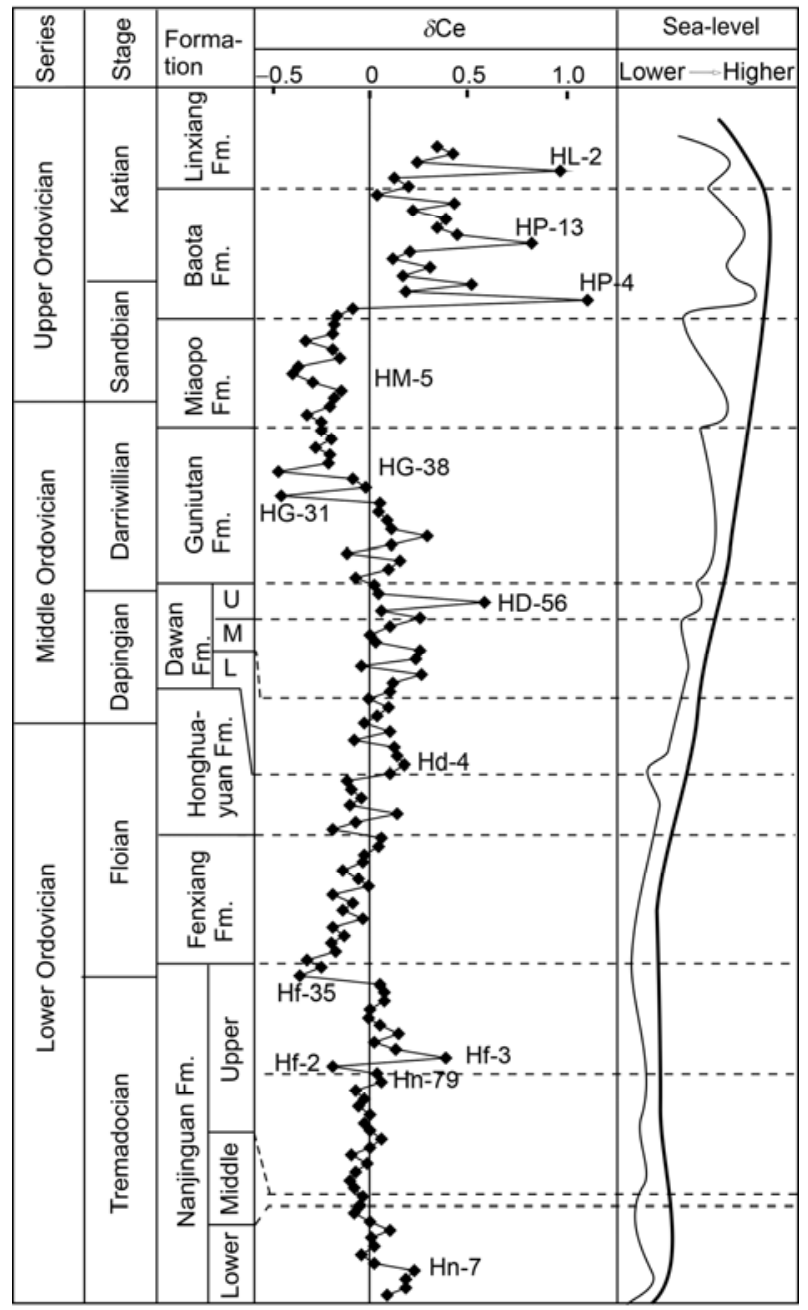

Figure 4 The evolution pattern of $\mathrm{Ce}$ anomalies for Ordovicion conodonts of Huanghuachang section, Yichang Area. $\delta$ Ce values are calculated by $\delta \mathrm{Ce}=\mathrm{Ce} /(\mathrm{La} * \mathrm{Pr})^{1 / 2}-1$. The sea-level fluctuation trend is modified from $[6,37]$.
Nanjinguan, Dawan, Baota and Linxiang formations deposited on the shelf-basin margin exhibit notable positive Ce anomalies, which indicate an oxygen-deficient environment.

There are two main reasons for the notable negative Ce anomalies in the Guniutan and Miaopo formations. One is related to the contribution of La-rich terrigenous clastics to the seawater REE of the Yangtze Basin during the formation of the foreland basin [2]. The other reason is closely related to regression during the late Darriwillian. An important piece of evidence of the regression in the Yichang area is the unconformity that is marked by the absence of conodonts between the Guniutan and Miaopo formations $[6,37]$. Because of the intense regression, the sedimentary environment of the Guniutan Formation was transformed from deep-water shelf at the base to oxygen-enriched shallow sea at the top, resulting in the depletion of $\mathrm{Ce}$ in the seawater by the oxidation of $\mathrm{Ce}^{3+}$ to $\mathrm{Ce}^{4+}$ and its incorporation into Fe-Mn nodules [36]. As for the Miaopo Formation, although the black shales were mainly developed in the hypoxic-reductive confined basins, the exact origin of the limestone is the saturated $\mathrm{CaCO}_{3}$ in the slightly-oxidized water of the basin margin, which is confirmed by the bone fragments of Cystoidea scattered in the nodular limestones [12].

Bulk sediment Ce anomalies (e.g. shale, carbonates and flints) have been extensively used in the past to reconstruct palaeo-redox conditions [29,36,38-40]. However, the reliability and applicability is still unclear. Early diagenesis probably changed the REE composition of the sedimentary rocks [41]. The tectonic setting is also an important influencing factor. The erosion of terrigenous material, especially volcaniclastics with enriched $\mathrm{La}$, may affect the REE distribution of seawater and exaggerate the Ce negative anomalies [22,26,38]. Additionally, it is important to note that the palaeo-redox conditions recorded by bulk sediment $\mathrm{Ce}$ anomalies may be inconsistent with the fact. For instance, as mentioned above, in oxygen-rich environments, $\mathrm{Ce}^{3+}$ can be oxidized to $\mathrm{Ce}^{4+}$ and incorporated into Fe-Mn nodules, resulting in the negative $\mathrm{Ce}$ anomalies of seawater. However, the subsequent deposition of those Fe-Mn nodules may compensate for the Ce negative anomalies of the sediment. In fact, the correlation of $(\mathrm{La} / \mathrm{Sm})_{\mathrm{N}}$ to $\delta \mathrm{Ce}$ (Figure 5) indicates that there is no correlation between terrigenous material and $\delta \mathrm{Ce}$ values. Additionally, the most negative $\mathrm{Ce}$ anomaly occurs in the Guniutan Formation, which has lower mud content (Figure 5). Thus, it can be concluded that the controlling factors on Ce anomaly should be the redox conditions or water depth rather than the mud content in the seawater.

\section{Conclusions}

The following conclusions can be drawn from the analyses of rare earth elements in the Ordovician conodonts of the 


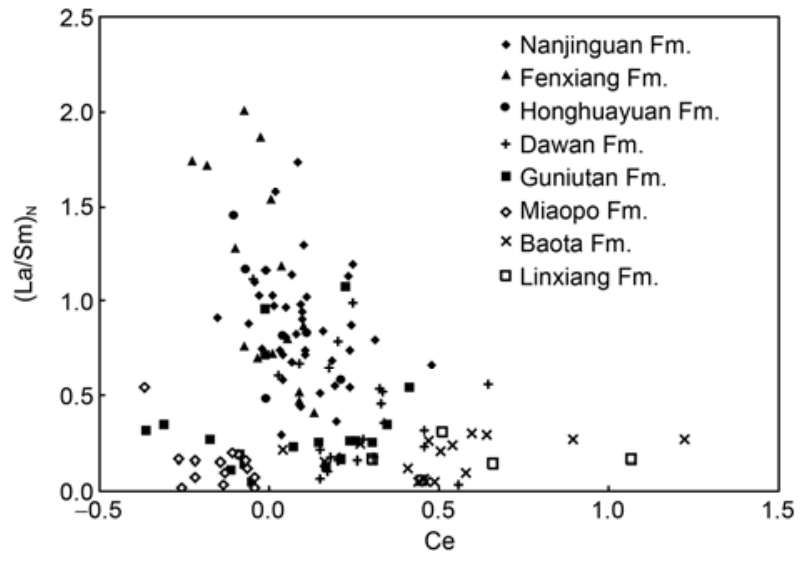

Figure 5 The Ce anomaly $(\delta \mathrm{Ce})$ vs. $(\mathrm{La} / \mathrm{Sm})_{\mathrm{N}}$ ratios for Ordovician conodonts in Huanghuachang section, Yichang.

Huanghuachang section.

(1) The REE of the conodonts may be a good indicator of REE distributions in palaeo-seawater, with adsorption being the main process of REE enrichment in the conodonts.

(2) Values of $(\mathrm{La} / \mathrm{Yb})_{\mathrm{N}}$ and $(\mathrm{La} / \mathrm{Sm})_{\mathrm{N}}$ are relatively large on the shallow-water carbonate platform to platform margin but relatively small on the open continental shelf to shelf basin. The $(\mathrm{La} / \mathrm{Yb})_{\mathrm{N}}$ and $(\mathrm{La} / \mathrm{Sm})_{\mathrm{N}}$ values of conodonts can be developed as a potential indicator of seawater depth.

(3) As the sedimentary environment changes from shallowwater carbonate platform to platform margin to open continental shelf to shelf basin, the REE distribution curves transform gradually from a right inclined pattern to a flat pattern, a left inclined pattern and finally a hat-shaped pattern, which can be considered to indicate the foreland basin. Therefore REE distribution patterns can be used to indicate environmental changes.

(4) The Ce in the Ordovician conodonts of the Huanghuachang section shows negative anomalies in shallow and oxidized environments and positive anomalies in the deep and anoxic environments. There is an increasing trend of positive anomalies as the water deepens. As an indicator of the palaeo-oceanic redox conditions or water depth, the $\mathrm{Ce}$ anomalies of conodonts may be a better geochemical tracer than those of the bulk sediments.

This work was supported by China Geological Survey (1212011121103 and 1212010710715) and the National Natural Science Foundation of China (40972003 and 40673020).

1 Wright J, Schrader H, Holser W T. Paleoredox variations in ancient oceans recorded by rare earth elements in fossil apatite. Geochim Cosmochim Acta, 1987, 51: 631-644

2 Grandjean P, Cappetta H, Albarède F. The REE and $\varepsilon \mathrm{Nd}$ of 40-70 Ma old fish debris from the West African platform. Geophys Res Lett, 1988, 15: 389-392

3 Girard C, Lécuyer C. Variations in Ce anomalies of conodonts through the Frasnian/Famennian boundary of Poland (Kowala-Holy Cross Mountains): Implications for the redox state of seawater and biodiversity. Palaeogeogr Palaeoclimatol Palaeoecol, 2002, 181: 299_ 311

4 Lécuyer C, Reynard B, Grandjean P. Rare earth element evolution of Phanerozoic seawater recorded in biogenic apatites. Chem Geol, 2004, 204: 63-102

5 Bolhar R, Van Kranendonk M J. A non-marine depositional setting for the northern Fortescue Group, Pilbara Craton, inferred from trace element geochemistry of stromatolitic carbonates. Precambrian Res, 2007, 155: 229-250

6 Chen X H, Zhang M, Wang C S. Ordovician Chitinozoans from South China (in Chinese). Beijing: Geological Publishing House, 2009. 1-261

7 Chen X H, Wang X F. Early Paleozoic chrono- and sequence-stratigraphy in the Yangtze Gorges area, China with an approach of palaeobiogeography. Gondwana Res, 1999, 2: 627-632

8 Wang X F, Ni S Z, Zeng Q L, et al. Biostratigraphy of the Yangtze Gorges Area (2). Early Paleozoic Era (in Chinese). Beijing: Geological Publishing House, 1987. 43-146

9 Chen X H, Wang X F, Li Z H, et al. Elaborate biostratigraphic subdivision and correlation of the basal Dawan Stage (Middle Ordovician) in Yangtze Platform, China (in Chinese). Acta Palaeont Sin, 2003, 42: 317-327

10 Zhou Z Q, Zhou Z Y, Yuan W W. Late Ordovician trilobite fauna and succession, Yichang, Hubei Province, China (in Chinese). J Stratigr, 2005, 44: 327-357

11 Wang X F, Svend S, Chen X H, et al. The global stratotype section and point for the base of the Middle Ordovician Series and the Third Stage (Dapingian). Epis, 2009, 32: 96-113

12 Chen X, Qiu J Y. Ordovician palaeoenvironmental reconstruction of Yichang area (in Chinese). J Stratigr, 1986, 10: 1-15

13 Zeng Q L. Ordovician brachiopod communities and eustatic changes of sea level in the eastern Yangtze Gorges area, China (in Chinese). Bull Yichang Inst Geol Min Res, 1991, 16: 19-39

14 Hu M Y, Gong W P, Xiao C T, et al. Facies and environment of Early Ordovician at Huanghuachang, Yichang, Hubei (in Chinese). Oil Gas Geol, 1996, 17: 347-352

15 Yuan W W, Zhou Z Y, Zhang J M, et al. Tremadocian trilobite biofacies in western Hunan-Hubei (in Chinese). J Stratigr, 2000, 24: 275-282

16 Zhou Z Y, Zhou Z Q, Yuan W W, et al. Late Ordovician trilobite biofacies and palaeogeographical development, western Hubei-Hunan (in Chinese). J Stratigr, 2000, 24: 249-263

17 Zhang T G, Shen Y A, Zhan R B, et al. Large perturbations of the carbon and sulfur cycle associated with the Late Ordovician mass extinction in South China. Geology, 2009, 37: 299-302

18 Trotter J A, Eggins M S. Chemical systematics of conodont apatite determined by laser ablation ICPMS. Chem Geol, 2006, 233: 196-216

19 Wang X F, Erdtmann B D, Hoffknecht A, et al. Bioclast ReflectanceA New Frontier of Organic Petrology. Beijing: Geological Publishing House, 1997. 1-80

20 Zhou L, Hu Z C, Yuan H L, et al. Geochemical characteristics of paleoseawater from the Early Ordovician of Yangtze Craton: Evidence from the trace elements in conodonts (in Chinese). Geochemistry, 2005, 34: 227-234

21 Elderfield H, Upstill-Goddard R, Sholkovitz E R. The rare earth element in river, estuaries, and coastal seas and their significance to the composition of ocean water. Geochim Cosmochim Acta, 1990, 54: 971-991

22 Bertram C J, Elderfield $\mathrm{H}$, Aldridge R J, et al. ${ }^{87} \mathrm{Sr} /{ }^{86} \mathrm{Sr},{ }^{143} \mathrm{Nd} /{ }^{144} \mathrm{Nd}$ and REEs in Silurian phosphatic fossils. Earth Planet Sci Lett, 1992, 113: 239-249

23 Reynard B, Lécuyer C, Grandjean P. Crystal-chemical controls on rare-earth element concentrations in fossil biogenic apatites and implication for paleoenvironmental reconstructions. Chem Geol, 1999, 155: 233-241

24 Grandjean-Lécuyer P, Feist R, Albarede F. Rare earth elements in old biogenic apatites. Geochim Cosmochim Acta, 1993, 57: 2507-2514

25 Gromet L P, Dymek R F, Haskin L A, et al. The North American Shale Composite: Its compilation, major and trace element character- 
istics. Geochim Cosmochim Acta, 1984, 48: 2469-2482

26 Lécuyer $\mathrm{C}$, Grandjean $\mathrm{P}$, Barrat $\mathrm{J}$ A, et al. $\delta^{18} \mathrm{O}$ and REE content of phosphatic brachiopods: A comparison between modern and Lower Paleozoic populations. Geochim Cosmochim Acta, 1998, 62: 2429_ 2436

27 Owen A W, Armstrong H A, Floyd J D. Rare earth element geochemistry of Upper Ordovician cherts from the Southern Upland of Scotland. J Geol Soc, 1999, 156: 191-204

28 Patricka D, Martin J E, Parris D C, et al. Paleoenvironmental interpretations of rare earth element signatures in mosasaurs (reptilia) from the Upper Cretaceous Pierre Shale, central South Dakota, USA. Palaeogeogr Palaeoclimatol Palaeoecol, 2004, 212: 277-294

29 Du Y S, Zhu J, Gu S Z, et al. Sedimentary geochemistry of the Cambrian-Ordovician cherts: Implication on archipelagic ocean of North Qilian orogenic belt. Sci China Ser D-Earth Sci, 2007, 50: 1628-1644

30 Zhang T G, Trela W, Jiang S Y, et al. Major oceanic redox condition change correlated with the rebound of marine animal diversity during the Late Ordovician. Geology, 2011, 39: 675-678

31 Turvey S T, Zhou Z Y. Arenig trilobite associations of Daping, Yichang, Hubei, South China. Acta Palaeont Sin, 2002, 41: 10-18

32 Xu X S, Wan F, Yin F G, et al. Environment facies, ecological facies and digenetic facies of Baota Formation, Late Ordovician (in Chinese). J Mineral Petrol, 2001, 21: 64-68

33 Wang X F, Chen X H. Palaeobiogeography and palaeoclimatology of Ordovician in China (in Chinese). Prof Pap Stratigr Palaeont, 1999,
(27): 24-27

34 Armstrong H A, Pearson D G, Griselin M. Thermal effects on rare earth element and strontium isotope chemistry in single conodont elements. Geochim Cosmochim Acta, 2001, 65: 435-441

35 Wright J, Seymour R S, Shaw H F. REE and Nd isotopes in conodont apatite: Variations with geological age and depositional environment. Geol Soc Am Spec Pap, 1984, (196): 325-340

36 Liu Y G, Miah M R U, Sehmitt R A. Cerium: A chemical tracer for paleo-oceanic redox conditions. Geochim Cosmochim Acta, 1988, 52: 1361-1371

37 Chen X H, Wang X F. Multiple stratigraphic subdivision and sea level changes of the Early Paleozoic in Yangtze Gorges area (in Chinese). Geol Min Res S Chin, 1999, 3: 1-11

38 Murray R W, Brinck R M B, Jones D L, et al. Rare earth elements as indicators of different marine depositional environments in chert and shale. Geology, 1990, 18: 268-271

39 Wilde P, Quinby-Hunt M S, Erdtmann B D. The whole-rock cerium anomaly: A potential indicator of eustatic sea level changes in shales of anoxic facies. Sediment Geol, 1996, 101: 43-53

40 Yan D T, Chen D Z, Wang Q C, et al. Geochemical changes across the Ordovician-Silurian transition on the Yangtze Platform, South China. Sci China Ser D-Earth Sci, 2009, 52: 38-54

41 De Bear H J W, German C R, Erdfiled H, et al. Rare earth element distributions in anoxic waters of Cariaco Trench. Geochem Cosmochim Acta, 1988, 52: 1203-1219

Open Access This article is distributed under the terms of the Creative Commons Attribution License which permits any use, distribution, and reproduction in any medium, provided the original author(s) and source are credited. 